\title{
IDENTIFICATION OF COMMON BEAN ALLELES RESISTANT TO ANTHRACNOSE USING RAPD
}

\author{
Ana L.M. Castanheira ${ }^{1}$, João B. dos Santos ${ }^{2}$, Daniel F. Ferreira ${ }^{3}$ and Leonardo C. Melo ${ }^{4}$
}

\begin{abstract}
RAPD markers were identified close to common bean alleles responsible for resistance to the fungus Colletotrichum lindemuthianum and may be useful in selecting plants resistant to this pathogen. DNA from $\mathrm{F}_{2}$ plants of the crosses Carioca $300 \mathrm{~V} \times \mathrm{P} 45$, Carioca 300V x Ouro and P24 x Ouro was amplified by RAPD. Line P45 has the Co.4 allele for resistance, and the Ouro cultivar has the Co.5 allele. The primer OPC08 amplified a DNA fragment of about 1059 bp linked to the Co.4 allele. The recombination frequency was $0.133(\mathrm{SE}=0.039 ; 95 \% \mathrm{Cl}=0.056-0.211)$. Using the primer OPF10 a DNA fragment of about $912 \mathrm{bp}$ was amplified and found to be associated with the Co.5 allele. The recombination frequency was 0.115 (SE = 0.038 ; $95 \% \mathrm{Cl}=0.041-0.189)$. A second marker (1122 pb) amplified by the OPR03 primer was identified in the population P24 $\mathrm{x}$ Ouro. The recombination frequency for this marker was 0.363 ( $\mathrm{SE}=0.081 ; 95 \% \mathrm{Cl}=0.205-0.522)$. Both these markers flanked the Co.5 allele. The markers identified in this study may be useful in identifying lines with the Co.4 and Co.5 alleles .
\end{abstract}

\section{INTRODUCTION}

Among pathogens of the common bean, anthracnose, caused by the fungus Colletotrichum lindemuthianum, is one of the most important, reducing crop yields throughout Brazil. Anthracnose can cause total loss of a crop when the temperature is cool and the relative humidity high, as often occurs in southeastern Brazil, particularly in the southern part of the State of Minas Gerais, where this disease can make the farming of this crop unfeasible (Rava et al., 1994). The problem is aggravated in plantations where irrigation may greatly increase the amount of inoculum in the field.

The natural resistance of the common bean to anthracnose is mediated by several independent genes which possess one or more alleles resistant to several races of $C$. lindemuthianum (Rava et al., 1994; Young and Kelly, 1996a,b; Basset, 1996; Kelly and Young, 1996). Cultivars with only one resistant allele can control the disease for only a few years until the appearance of new races of the fungus. One way of making the resistance more durable is to incorporate resistant alleles from different genes into a selected cultivar. The principal difficulty with this approach is the time needed to identify the plants with resistant alleles since this generally requires systematic inoculations with different races of the fungus. An alternative means of identifying these alleles is by using RAPD (random amplified polymorphic DNA) markers.

Among the alleles for resistance, Co.4 of the TO line and Co.5 of the TU line are resistant to several races

\footnotetext{
${ }^{1}$ Agronomia, UFLA, Lavras, MG, Brasil.

${ }^{2}$ Departamento de Biologia, UFLA, Caixa Postal 37, 37200-000 Lavras, $M G$, Brasil. Send correspondence to J.B.S.

${ }^{3}$ Departamento de Estatística, UFLA, Lavras, MG, Brasil.

${ }^{4}$ Agronomia/Plant Genetics and Breeding, UFLA, Lavras, MG.
}

of the pathogen and are still efficient in most areas of cultivation in Brazil (Rava et al., 1994). Alleles Co.4 and Co.5 have already been incorporated into line P45 and cultivar Ouro, respectively, making these plants a useful source of alleles for improving resistance. However, the Co.4 allele has still not been tagged by RAPD markers and it has not been possible to reproduce the marker linked to the Co.5 allele identified by Young and Kelly (1996a). The aim of this study was to identify RAPD markers associated with the Co.4 and Co.5 alleles.

\section{MATERIAL AND METHODS}

\section{Crosses, $F_{1}, F_{2}$ and $F_{3}$ generations}

The following crosses were made: Carioca $300 \mathrm{~V}$ x P45, Carioca 300V x Ouro and P24 x Ouro. The Carioca $300 \mathrm{~V}$ line was selected from the cultivar Carioca and possesses excellent agronomic phenotypes, but is susceptible to $C$. lindemuthianum. P45 was selected from the population Carioca $\mathrm{X}$ TO and possesses a phenotype similar to the Carioca cultivar, as well as resistance to the pathogen attributable to allele Co.4. The Ouro cultivar possesses small, yellow seeds, growth habit II and the resistance allele Co.5. Line P24, which is derived from a cross between Eriparza and Diacol Calima, possesses dark yellow, medium-sized seeds and also has a resistance allele to $C$. lindemuthianum.

$\mathrm{F}_{1}$ and $\mathrm{F}_{2}$ generations were obtained for each cross. Approximately $2 \mathrm{~g}$ of young leaves were collected for DNA extraction from each $\mathrm{F}_{2}$ plant. The seeds of each $\mathrm{F}_{2}$ plant were harvested separately and provided an $\mathrm{F}_{3}$ family. Twelve plants from each family were used to evaluate resistance to the pathogen. This evaluation was done in the $\mathrm{F}_{3}$ because of the need to identify homozygous $\mathrm{F}_{2}$ plants, with resistant or susceptible alleles. The resistance of each $\mathrm{F}_{3}$ family was examined by inoculating 8-10-day-old plants 
with race 89 of the fungus. The inoculum consisted of a suspension of $1.2 \times 10^{6}$ spores $/ \mathrm{ml}$.

\section{DNA extraction}

Young leaves from $\mathrm{F}_{2}$ plants were ground with sand and $10 \mathrm{ml}$ of extraction buffer (100 mM Tris, $\mathrm{pH} 8.0$, containing $2 \%$ CTAB, $20 \mathrm{mM}$ EDTA, $1.4 \mathrm{M} \mathrm{NaCl}, 1 \%$ PVP and $20 \mu \mathrm{l}$ of $\beta$-mercaptoethanol) at $65^{\circ} \mathrm{C}$ (Rogers and Bendich, 1988). The ground material was incubated in a water bath at $65^{\circ} \mathrm{C}$ for $30-60 \mathrm{~min}$ after which $10 \mathrm{ml}$ of chloroform:isoamyl alcohol $(24: 1, \mathrm{v} / \mathrm{v})$ was added and the mixture centrifuged for $10 \mathrm{~min}$ at 4,000 rpm. The nucleic acid in the supernatant was then precipitated with $30 \mathrm{ml}$ of $95 \%$ ethanol:7.5 $\mathrm{M}$ ammonium acetate $(6: 1, \mathrm{v} / \mathrm{v})$. After at least $60 \mathrm{~min}$ at $-20^{\circ} \mathrm{C}$ the nucleic acid was collected and dissolved in $1 \mathrm{mM}$ Tris $-0.1 \mathrm{mM}$ EDTA (TE) followed by a second extraction with chloroform:isoamyl alcohol. The mixture was then centrifuged at $14,000 \mathrm{rpm}$ for $5 \mathrm{~min}$ at room temperature. The supernatant was collected and three volumes of $95 \%$ ethanol:3 M sodium acetate $(20: 1, \mathrm{v} / \mathrm{v})$ added, after which the extract was stored at $-20^{\circ} \mathrm{C}$ for at least $60 \mathrm{~min}$. The precipitated DNA was collected by centrifugation, dissolved in about $300 \mu \mathrm{l}$ of TE, and then diluted to $10 \mathrm{ng} / \mu \mathrm{l}$.

\section{RAPD}

The DNA from 6-14 resistant $\mathrm{F}_{2}$ homozygous plants was pooled as was the DNA from a similar number of susceptible plants (Michelmore et al., 1991). DNA from the cross Carioca 300V x P45 was analyzed with 432 10mer primers (Operon) or a mix of pairs. The cross Carioca $300 \mathrm{~V} x$ Ouro was analyzed with 357 primers and the cross P24 x Ouro with 387. The primers used were from A to T kits, each one with 20 primers.

The RAPD reaction (Williams et al., 1990; Santos et al., 1994) contained $20 \mathrm{ng}$ of DNA, $100 \mu \mathrm{M}$ dNTP, 0.4 $\mu \mathrm{M}$ primer, 0.6 units of Taq DNA polymerase, $2.5 \mathrm{mM}$

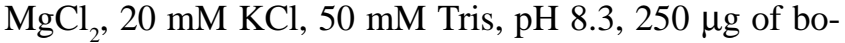
vine serum albumin/ml, 1.0\% Ficoll 70 and $1 \mathrm{mM}$ tartrazine. The reactions were set up in glass capillary tubes in an air thermocycler (Idaho Technology) programmed for 40 cycles. The first two cycles consisted of denaturation for $60 \mathrm{~s}$ at $91^{\circ} \mathrm{C}$, annealing for $7 \mathrm{~s}$ at $42^{\circ} \mathrm{C}$ and elongation for $70 \mathrm{~s}$ at $72^{\circ} \mathrm{C}$; the subsequent 38 cycles were run with the denaturation time reduced to $1 \mathrm{~s}$ at $91^{\circ} \mathrm{C}$. The reaction was concluded by incubating for $4 \mathrm{~min}$ at $72^{\circ} \mathrm{C}$. After amplification, the DNA fragments were separated by electrophoresis in $1 \%$ agarose gels, which were then stained with ethidium bromide, and photographed under UV light with Polaroid 667 film.

\section{Statistical and genetic analysis}

Initially, genetic control of the resistance of the common bean to $C$. lindemuthianum and of the RAPD markers was determined. The results were tested by $\chi^{2}$.

The recombination frequencies between the markers and the resistance alelles were estimated by analyzing the DNA of $\mathrm{F}_{2}$ plants using the same primer identified with pooled DNA. The estimates were obtained by the maximum likelihood method (Allard, 1956; Elandt-Johnson, 1971). In the case of markers flanking a resistance allele, interference was considered absent based on the criteria of Van Ooijen (1992), after modification of the codominant model, for use with dominant markers.

\section{RESULTS AND DISCUSSION}

The analysis of the pooled DNA identified a segregant marker of about 1059-base pairs (bp) that was amplified by primer OPC08 (5'TGGACCGGTTG3'). This marker was probably linked to the Co.4 allele since all the plants which provided DNA for this pool have this band, although it also occurred in $30 \%$ of the plants which formed the susceptible pool (Figure 1).

The reaction of the common bean to the pathogen was monogenic (Table I), with dominance of the Co.4 allele $\left(\chi^{2}=0.015, \mathrm{P}=0.903\right)$. The inheritance of the marker identified by primer OPC08 $\left(\chi^{2}=0.370, \mathrm{P}=0.543\right)$ was monogenic and dominant, indicating its viability as a ge-

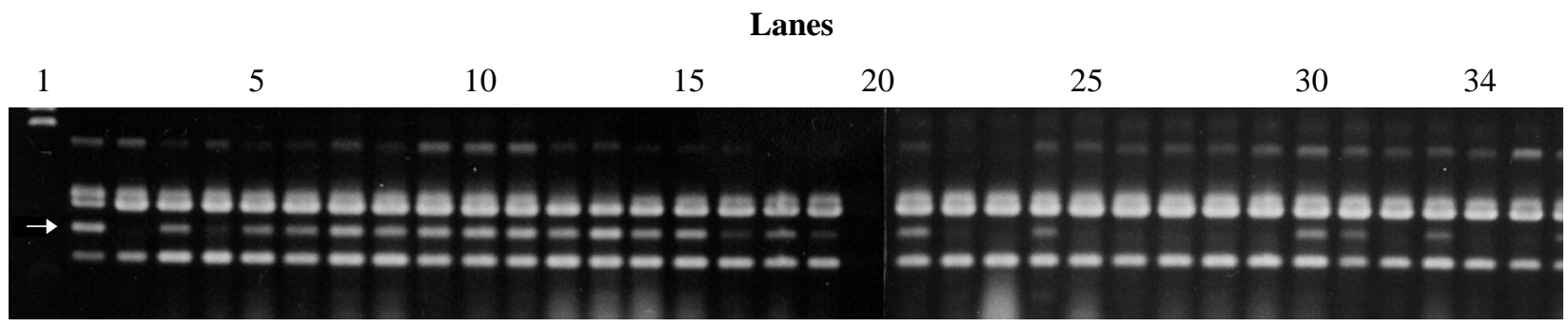

Figure 1 - RAPD pattern produced by primer OPC08 in the parents and components of resistant and susceptible bulks. The band indicated by the arrow is linked to the Co.4 allele. The band pattern of the Carioca 300V parent (lane 2), P45 parent (lane 3), resistant DNA pool (lanes 4 and 20), susceptible DNA pool (lanes 5 and 21), homozygous resistant plants (lanes 6-19) and homozygous susceptible plants (lanes 22-34) are shown. Lane 1, DNA size markers (Lambda-HindIII). 
Table I - Number of $\mathrm{F}_{2}$ plants with phenotypes resistant or susceptible to Colletotrichum lindemuthianum, and the occurrence of a linked band produced by the primer OPC08, for the cross Carioca $300 \mathrm{~V} \times \mathrm{P} 45$.

\begin{tabular}{|ccccccc|}
\hline \multicolumn{2}{c}{ Reaction to $C$. lindemuthianum } & & \multicolumn{2}{c|}{ OPC08 primer } \\
\cline { 1 - 2 } Phenotypes & $\begin{array}{c}\text { Number of } F_{2} \\
\text { plants }\end{array}$ & $\begin{array}{c}\text { Expected number } \\
\text { of } F_{2} \text { plants }\end{array}$ & & Linked band & $\begin{array}{c}\text { Number of } F_{2} \\
\text { plants }\end{array}$ & $\begin{array}{c}\text { Expected number } \\
\text { of } F_{2} \text { plants }\end{array}$ \\
\hline Resistant & 67 & 67.5 & & Present & 70 & 67.5 \\
Susceptible & 23 & 22.5 & & Absent & 20 & 22.5 \\
\hline
\end{tabular}

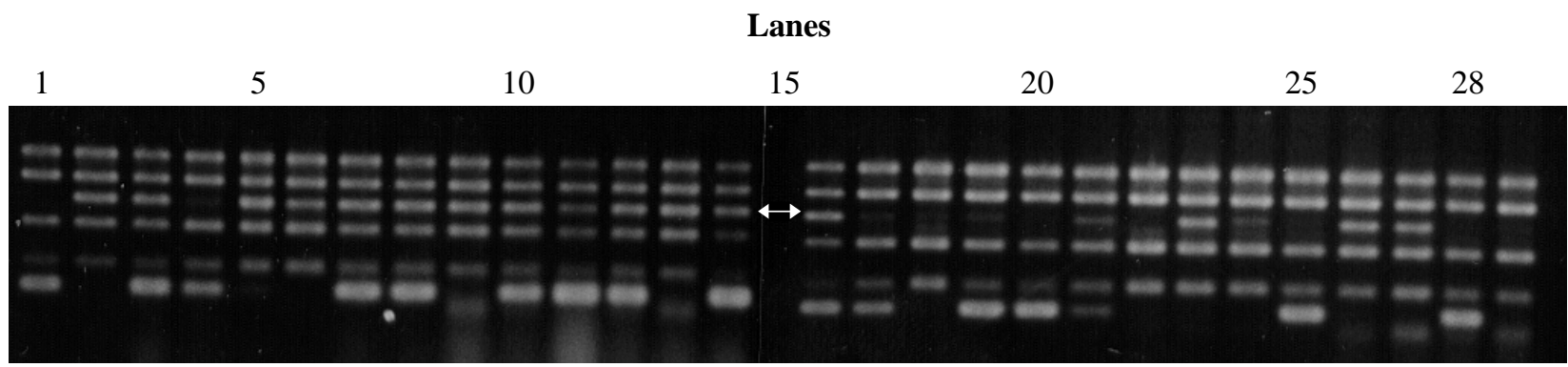

Figure 2 - RAPD pattern produced by the primer OPF10 in the parents and components of resistant and susceptible bulks. The band indicated by the arrow is linked to the Co.5 allele. The band pattern of the Carioca 300V parent (lane 1), Ouro parent (lane 2), resistant DNA pool (lanes 3 and 15), susceptible DNA pool (lanes 4 and 16), homozygous resistant plants (lanes 5-14), and homozygous susceptible plants (lanes 17-28) are shown.

netic marker. The relationship between the resistance to C. lindemuthianum and the occurrence of the marker identified by primer OPC08 $\left(\chi^{2}=37.763, \mathrm{P}=0.000\right)$ confirms that the distributions of the two loci were not independent.

The estimated recombination frequency for the marker and the Co.4 allele in the P45 parent was 0.133 (S.E. $=0.039 ; 95 \% \mathrm{CI}=0.056-0.0211)$. The distance of the marker relative to the resistance allele indicated that if indirect selection of the plants carrying the marker were made in the $\mathrm{F}_{2}$ population, $6.2 \%$ of them would be susceptible.

The marker identified by primer OPF10 (5'GGAA GCTTGG3'; Figure 2) seems to be linked to allele Co.5, derived from the cross Carioca $300 \mathrm{~V}$ x Ouro. Again, the resistance to the pathogen showed monogenic inheritance and confirmed the dominance of the Co.5 allele. There was a slight excess of the dominant class (Table III; $\chi^{2}=$ $4.267, \mathrm{P}=0.039$ ), possibly because of the small population size used. The marker generated by primer OPF10 also showed monogenic inheritance and dominance (Table III; $\chi^{2}=3.267, \mathrm{P}=0.071$ ).

When the population P24 x Ouro was used, a marker of about 912 bp amplified by primer OPF10 was seen, along with a second marker of about 1122 bp (Figure 3), produced by primer OPR03 (5'ACACAGAGGGG3'). The presence of the band in plant number 10 suggests that the $\mathrm{F}_{3}$ family reaction to the fungus was not correctly evaluated (Figure 3); this sample probably came from a heterozygous $\mathrm{F}_{2}$ plant. These markers were linked to the Co.5 allele (Table IV). In this population, a second resistance
Table II - Relationship between the $\mathrm{F}_{2}$ bean phenotypes associated with resistance to Colletotrichum lindemuthianum and the occurrence of the marker generated by primer OPC08.

\begin{tabular}{|lcc|}
\hline Phenotype & $\begin{array}{c}\text { Number of } \\
\mathrm{F}_{2} \text { plants }\end{array}$ & $\begin{array}{c}\text { Expected number } \\
\text { of } \mathrm{F}_{2} \text { plants }\end{array}$ \\
\hline Resistant with marker & 63 & 50.6 \\
Resistant without marker & 4 & 16.9 \\
Susceptible with marker & 7 & 16.9 \\
Susceptible without marker & 16 & 5.6 \\
\hline
\end{tabular}

gene segregated from the P24 parent. The dominant allele of this gene was responsible for the resistance which produced 15 resistant plants and one susceptible plant in the $\mathrm{F}_{2}\left(\right.$ Table IV; $\left.\chi^{2}=0.009, \mathrm{P}=0.924\right)$. Both markers showed monogenic inheritance and dominance; $\chi^{2}$ values for the markers amplified by primers OPF10 and OPR03 were $2.585(\mathrm{P}=0.108)$ and $0.364(\mathrm{P}=0.546)$, respectively. When the three loci were considered simultaneously (Table $\mathrm{V})$, the assortment of at least two of them was not independent $\left(\chi^{2}=36.733, \mathrm{P}=0.000\right.$; Tables II and III).

The recombination frequency between the marker generated by primer OPF10 and the Co.5 allele was 0.115 (S.E. $=0.038 ; 95 \% \mathrm{CI}=0.041-0.189)$. For the marker produced by primer OPR03, the recombination frequency was 0.363 (S.E. $=0.081 ; 95 \% \mathrm{CI}=0.205-0.522$ ). These results indicate that the two markers flank the resistance allele. Although neither is very close to this allele, if the two were used together for indirect selection of the Co.5 allele 


\section{Lanes}

$\begin{array}{lllll}1 & 5 & 9 & 10 & 14\end{array}$

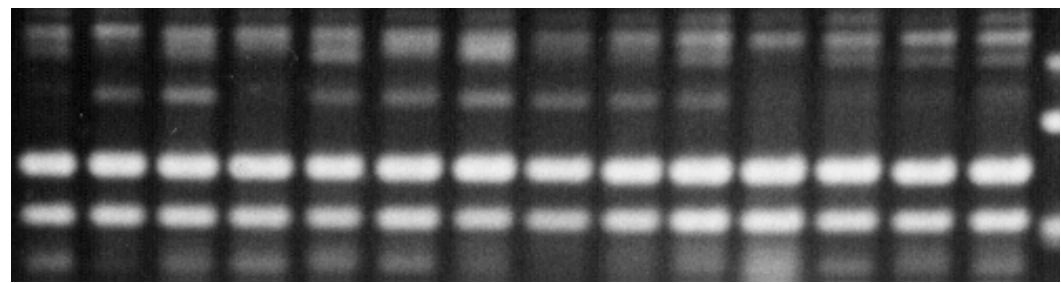

Figure 3 - RAPD pattern produced by the primer OPR03 in the components of resistant and susceptible bulks. The band indicated by the arrow is linked to the Co.5 allele. The band patterns for homozygous resistant plants (lanes 1-9), and homozygous susceptible plants (lanes 10-14) are shown.

Table III - Number of $\mathrm{F}_{2}$ bean plants with phenotypes resistant or susceptible to Colletotrichum lindemuthianum, and the occurrence of a linked band produced by primer OPF10, for the cross Carioca $300 \mathrm{~V}$ x Ouro.

\begin{tabular}{|ccccccc|}
\hline \multicolumn{2}{c}{ Reaction to $C$. lindemuthianum } & & \multicolumn{3}{c|}{ OPF10 primer } \\
\cline { 1 - 2 } \cline { 5 - 6 } Phenotypes & $\begin{array}{c}\text { Number of } \\
\mathrm{F}_{2} \text { plants }\end{array}$ & $\begin{array}{c}\text { Expected number } \\
\text { of } \mathrm{F}_{2} \text { plants }\end{array}$ & & Linked band & $\begin{array}{c}\text { Number of } \\
\mathrm{F}_{2} \text { plants }\end{array}$ & $\begin{array}{c}\text { Expected number } \\
\text { of } \mathrm{F}_{2} \text { plants }\end{array}$ \\
\hline Resistant & 68 & 60 & & Present & 67 & 60 \\
Susceptible & 12 & 20 & & Absent & 13 & 20 \\
\hline
\end{tabular}

Table IV - Number of $\mathrm{F}_{2}$ bean plants with resistant or susceptible phenotypes and occurrence of linked bands generated by the primers OPF10 and OPR03, for the cross P24 x Ouro.

\begin{tabular}{|c|c|c|c|c|c|c|c|c|}
\hline \multicolumn{3}{|c|}{ Reaction to C. lindemuthianum } & \multicolumn{3}{|c|}{ OPF10 primer } & \multicolumn{3}{|c|}{ OPR03 primer } \\
\hline Phenotypes & $\begin{array}{l}\text { Number of } \\
\mathrm{F}_{2} \text { plants }\end{array}$ & $\begin{array}{l}\text { Expected number } \\
\text { of } F_{2} \text { plants }\end{array}$ & $\begin{array}{l}\text { Linked band - } \\
\text { OPF10 }\end{array}$ & $\begin{array}{l}\text { Number of } \\
F_{2} \text { plants }\end{array}$ & $\begin{array}{l}\text { Expected number } \\
\text { of } F_{2} \text { plants }\end{array}$ & $\begin{array}{l}\text { Linked band - } \\
\text { OPR03 }\end{array}$ & $\begin{array}{l}\text { Number of } \\
\mathrm{F}_{2} \text { plants }\end{array}$ & $\begin{array}{l}\text { Expected number } \\
\text { of } F_{2} \text { plants }\end{array}$ \\
\hline Resistant & 124 & 123.75 & Present & 107 & 99 & Present & 102 & 99 \\
\hline Susceptible & 8 & 8.25 & Absent & 25 & 33 & Absent & 30 & 33 \\
\hline
\end{tabular}

Table $\mathbf{V}$ - Observed and expected numbers of $\mathrm{F}_{2}$ bean plants assuming independent distribution of the fungus reaction and of the bands generated by the primers OPF10 and OPR03.

\begin{tabular}{|lllllllll|}
\hline Phenotype* Re RF & Re Rf & RerF & Rerf & SuRF & SuRf & SurF & SurF \\
\hline No. of F F $_{2}$ plants & 83 & 17 & 22 & 2 & 0 & 2 & 2 & 4 \\
Expected no. of & 69.6 & 23.2 & 23.2 & 7.7 & 4.6 & 1.6 & 1.6 & 0.5 \\
F $_{2}$ plants & & & & & & & & \\
\hline
\end{tabular}

$* \mathrm{Re}=$ resistant $\mathrm{Su}=$ susceptible $; \mathrm{R}$ or $\mathrm{F}=$ presence of the band; $\mathrm{r}$ or $\mathrm{f}=$ absence of the band.

in an $\mathrm{F}_{2}$ population, $83 \%$ of the plants with one or both markers would be expected to be resistant to the fungus.

Most of the resistance alleles against anthracnose confer complete resistance and therefore exert considerable selection pressure on the fungus. An alternative approach for increasing the useful life of resistance alleles from different genes is to incorporate several into a single cultivar (Pedersen, 1988; Mundt, 1990, 1991; Young and
Kelly, 1996a,b; Miklas et al., 1996; Ito et al., 1996). However, the identification of plants carrying two or more resistance alleles of different genes using the standard inoculation test is an almost impossible task since several races of fungus would be needed to screen for specific resistance alleles. In such a case, the use of molecular markers provides a rapid alternative in selecting genotypes that constitute a pyramid (Adam-Blondon et al., 1994; Miklas 
et al., 1996; Young and Kelly, 1996b). The markers identified in this study may be useful in identifying lines with the Co.4 and Co.5 alleles, or may be used when the races necessary for screening resistant plants by standard inoculation test are not available. Since these markers are relatively distant from the resistance alleles, effort should be made to identify others closer to the alleles of interest.

\section{ACKNOWLEDGMENTS}

Research supported by FAPEMIG and CNPq.

\section{RESUMO}

Marcadores RAPD foram identificados próximos de alelos do feijão responsáveis pela resistência ao Colletotrichum lindemuthianum, visando auxiliar na seleção de plantas resistentes ao patógeno. Empregou-se o método dos bulks segregantes de DNA extraídos de plantas $\mathrm{F}_{2}$ dos seguintes cruzamentos: Carioca 300V x P45, Carioca 300V x Ouro e P24 x Ouro. A linhagem P45 é portadora do alelo Co.4 de resistência e o cultivar Ouro é portador do alelo Co.5, os quais foram marcados. Procedeu-se à reação RAPD dos bulks e foi identificado o iniciador OPC08 que amplificou um fragmento de DNA com cerca de $1059 \mathrm{pb}$, ligado ao alelo Co.4. A frequiência de recombinação foi de 0,133 (erro padrão 0,039 ) e o intervalo de confiança foi 0,056 e 0,211 , com $95 \%$ de probabilidade. Em relação ao alelo Co.5 foi identificado um fragmento de DNA amplificado pelo iniciador OPF10 com cerca de $912 \mathrm{pb}$, na análise dos bulks provenientes dos cruzamentos Carioca 300V x Ouro e P24 x Ouro. A frequiência de recombinação foi de 0,115 (erro padrão 0,038 ) e o intervalo de confiança foi 0,041 e 0,189 . Um segundo marcador foi identificado a partir da análise da população P24 x Ouro, resultante da amplificação pelo iniciador OPR03, e possui cerca de $1122 \mathrm{pb}$. A freqüência de recombinação foi 0,363 (erro padrão 0,081 ) e o intervalo de confiança variou de 0,205 a 0,522. Constatou-se que esses dois marcadores estão flanqueando o alelo Co.5 e a seleção de plantas resistentes de uma população $\mathrm{F}_{2}$ por meio dos marcadores será eficiente em $83 \%$ dos casos.

\section{REFERENCES}

Adam-Blondon, A.F., Sévignac, M., Bannerot, H. and Dron, M. (1994). SCAR, RAPD and RFLP markers linked to a dominant gene (Are) conferring resistance to anthracnose in common bean. Theor. Appl.
Genet. 88: 865-870.

Allard, R.E. (1956). Formulas and tables to facilitate the calculation of recombination values in heredity. Hilgardia 24: 235-279.

Basset, M.J. (1996). List of genes - Phaseolus vulgaris L. Ann. Rep. Bean Improv. Coop. 39: 1-19.

Elandt-Johnson, R.C. (1971). Probability Models and Statistical Methods in Genetics. John Wiley \& Sons, New York, pp. 592.

Ito, M.F., Carbonell, S.A.M., Pompeu, A.S. and Lot, R.C. (1996). Resistência do feijoeiro a Colletotrichum lindemuthianum e variabilidade fisiológica do patógeno. In: Resumos da V Reunião Nacional de Pesquisa de Feijão, Goiânia, EMBRAPA/CNPAF, Vol. 1, pp. 236-238.

Kelly, J.D. and Young, R.A. (1996). Proposed symbols for anthracnose resistance genes. Ann. Rep. Bean Improv. Coop. 39: 20-24.

Michelmore, R.H., Paran, I. and Kesseli, R.V. (1991). Identification of markers linked to disease-resistance genes by bulked segregant analysis: A rapid method to detect markers in specific genomic regions by using segregant populations (RAPD/RFLP). Proc. Natl. Acad. Sci. USA 88: 9828-9832.

Miklas, P.N., Afanador, L. and Kelly, J.D. (1996). Recombination-facilitated marker-assisted selection for disease resistance in common bean. Ann. Rep. Bean Improv. Coop. 39: 54 (Abstract).

Mundt, C.C. (1990). Probability of mutation to multiple virulence and durability of resistance gene pyramids. Phytopathology 80: 221-223.

Mundt, C.C. (1991). Probability of mutation to multiple virulence and durability of resistance gene pyramids: further comments. Phytopathology 81: 240-242.

Pedersen, W.L. (1988). Pyramiding major resistance genes for resistance to maintain residual effects. Annu. Rev. Phytopathol. 26: 369-378.

Rava, C.A., Purchio, A.F. and Sartorato, A. (1994). Caracterização de patótipos de Colletotrichum lindemuthianum que ocorrem em algumas regiões produtoras de feijoeiro comum. Fitopatol. Bras. 19: 167-173.

Rogers, S.O. and Bendich, A.J. (1988). Extraction of DNA from plant tissues. In: Plant Molecular Biology Manual A6 (Gelvin, S. and Schilperoort, R.A., eds.). Kluwer Academic Publishers, Dordrecht, The Netherlands, pp. 1-10.

Santos, J.B. dos, Nienhuis, J., Skroch, P., Tivang, J. and Slocum, M.K. (1994). Comparison of RAPD and RFLP genetic markers in determining genetic similarity among Brassica oleracea L. genotypes. Theor. Appl. Genet. 87: 909-915.

Van Ooijen, J.W. (1992). Accuracy of mapping quantitative trait loci in autogamous species. Theor. Appl. Genet. 84: 803-811.

Williams, J.G.K., Kubelik, A.R., Livar, K.J., Rafalski, J.A. and Tingey, S.V. (1990). DNA polymorphisms amplified by arbitrary primers are useful as genetic markers. Nucleic Acids Res. 18: 6531-6535.

Young, R.A. and Kelly, J.D. (1996a). Characterization of genetic resistance to Colletotrichum lindemuthianum in common bean differential cultivars. Plant Dis. 80: 650-654.

Young, R.A. and Kelly, J.D. (1996b). Gene pyramiding using marker assisted selection for stable resistance to bean anthracnose. Ann. Rep. Bean Improv. Coop. 39: 57-58.

(Received July 25, 1998) 
